\title{
Firm Heterogeneity, Political Risks and OFDI Firms' Performance
}

\author{
Jiaqi Luo, Liyan Liu* \\ School of Economics and Management, Beijing Institute of Petrochemical Technology, Beijing, China \\ Email: *lucyliuliyan@bipt.edu.cn
}

How to cite this paper: Luo, J. Q., \& Liu, L. Y. (2021). Firm Heterogeneity, Political Risks and OFDI Firms' Performance. American Journal of Industrial and Business Management, 11, 621-634.

https://doi.org/10.4236/ajibm.2021.116040

Received: May 19, 2021

Accepted: June 6, 2021

Published: June 9, 2021

Copyright $\odot 2021$ by author(s) and Scientific Research Publishing Inc. This work is licensed under the Creative Commons Attribution International License (CC BY 4.0).

http://creativecommons.org/licenses/by/4.0/

\begin{abstract}
This study was focused on the impacts of firm heterogeneity and political risks of destination countries on China's OFDI firms. A sample of 538 Chinese manufacturing firms investing in ASEAN countries are investigated from year 2005 to year 2013. Factors indicating firm heterogeneity as total assets, sectors of investment, location, operating experience, OFDI experience and export status are applied, while factors as political stability and government effectiveness of destination countries are applied, and economic environment as openness, market size, level of affluence of residents and labor size of destination countries are used as control variables. Findings show that assets level is an important factor for OFDI firms' performance, and China's OFDI firms investing in ASEAN countries have presented a risk preference.
\end{abstract}

\section{Keywords}

Firm Heterogeneity, Political Risks, OFDI Firms’ Performance, ASEAN

\section{Introduction}

Foreign investment is an important manifestation of a country's economic development and its international social and economic status. In the year of 2019, China's OFDI (Outward Foreign Direct Investment) reached the second place in the world, and Chinese enterprises have become one of the core forces of global multinational corporations' outbound investment. Due to the different characteristics of foreign investment enterprises, the difference of their foreign investment performance is also significant.

With the gradual implementation of the "The Belt and Road Initiative" policy, China's exchanges with countries along the "The Belt and Road Initiative" have 
further accelerated the worldwide pace of enterprises. The distribution of ASEAN countries is concentrated in "The Belt and Road Initiative", which provides great convenience for the investment of Chinese enterprises. ASEAN has also become the second largest region in the total amount of Chinese investment. Among them, China's total investment in Singapore and Indonesia far exceeds that of other ASEAN countries. From 2013 to 2019, China's cumulative direct investment in the "The Belt and Road Initiative" countries amounted to $\$ 113.11$ billion dollars. From the perspective of composition, the investment mainly focused on Singapore, Indonesia, Vietnam, Thailand and other ASEAN countries. Along with the high growth tendency of China's direct investment in ASEAN countries, some disadvantages have gradually emerged. The ten ASEAN countries are all developing countries. The weak economic foundation, unstable policy environment and unstable political situation make the risk of investment along the "The Belt and Road Initiative" higher, which has brought a great impact on the investment of Chinese firms.

Existing studies on foreign investment and investment performance mainly focus on the impact of OFDI on firm performance, on the impact of firm heterogeneity on OFDI, or on the impact of political risk on OFDI. Using the data of Chinese industrial firms from 2005 to 2013, this paper explores the impact of firm heterogeneity and political risk on enterprise performance in industrial investment in ASEAN countries, which aims to provide an effective reference for firms from developing countries to invest abroad.

\section{Literature Review}

OFDI is the key development strategy for enterprises. It can not only help enterprises expand overseas markets, reduce trade barriers, integrate and utilize international resources (Helpman, Melitz, \& Yeaple, 2004), but can also facilitate enterprises to obtain financial and trade opportunities, optimize their industrial structure and promote continuous development of enterprises (Morck et al., 2008). Botirjan Baltabaev (2012) used the systematic GMM estimation method to analyze the panel data of 46 countries from 1974 to 2008, adopted the new foreign direct investment tool, and found that FDI increased the growth of total factor productivity (TFP). Moreover, the positive effect of FDI on total factor productivity growth depends on the recipient country's absorptive capacity in terms of the technology leader (technology gap). Our findings suggest that countries with larger technological gaps appear to benefit more from FDI, thus we support the theory of relative backwardness advantage. Yang, Shen and Yin (2019) found through empirical research based on data at the enterprise level that, OFDI has a promoting effect on enterprise output. However, different types of OFDI have different influences on output. The commercial-service type and the forward vertical type of OFDI can promote enterprise output; horizontal OFDI can promote enterprise output only when the proportion of intermediate exports is higher than the threshold value; backward vertical OFDI can promote 
enterprise output only when the proportion of intermediate imports is higher than the threshold value. Horizontal OFDI which is characterized as researchoriented and development-oriented types as well as the type with no intermediate product has a significant "crowding out" effect on output.

In terms of heterogeneity, Li Hongya (2021) studied that it is of great significance for enterprises to "go out" to seek higher technologies for productivity improvement. Based on the perspective of seeking technological motivation of OFDI, this empirical study is conducted with the data of China's OFDI enterprises. The results show that the stronger the motivation is, the higher the productivity will be. In other words, investment in countries with higher technological innovation level will improve the productivity. The influence of seeking motivation on firm productivity is not only heterogeneous but also different between host country and region. Therefore, it is considered that enterprises should consider the heterogeneity and implement it in different categories when implementing "going out" to strengthen technology. Wen Chunyan (2020) analyzed the difference in the impact of manufacturing homogeneity and heterogeneity of market power on total factor productivity. In addition, leverage deviation of non-financial enterprises will also have an impact on the operating efficiency of enterprises (Tao Changqi \& Xu Dongmei, 2020). Cong Hao (2020) studied the effects of product differentiation, productivity level and export development on China's OFDI. Heterogeneity of corporate executives (Yan Jia, 2019) included the impact of age and educational background on enterprises. The research results provide new ideas for building corporate senior management teams and policy suggestions for promoting innovation-driven strategies of enterprises.

In terms of the influence of political risk on OFDI, Xu Junwei (2021) took RMB internationalization and "The Belt and Road Initiative" as the starting point to give suggestions on the political risk of OFDI of Chinese enterprises. He believed that China should strive to shape the good legal credit of RMB, strengthen the institutionalized construction of economic relations with countries along the Belt and Road, improve the supervision system of RMB offshore market, establish the circulation and flow mechanism of RMB and gradually promote the legal construction of RMB internationalization. Lin Zhenxiong et al. (2020) adopted the method of fictitious variables to select 1124 outbound investment projects from 2013 to 2017 and concluded that exchange rate fluctuations had a strong inhibiting effect on China's outbound investment. With the increase of exchange rate fluctuations, Chinese enterprises will reduce their overseas investment. On the contrary, less exchange rate volatility will lead to more outbound investment by Chinese companies. Mamta Chowdhury (2014) took 156 developed and developing countries as the research objects and used panel data to discuss the relationship between FDI and institutional factors. The results show that corruption significantly reduces FDI inflows, while democracy, rule of law, government stability and major economic factors have a significant 
positive impact on FDI inflows. In most cases, the influence of institutions is far greater than that of economic and policy variables. Thus, policies attracting more foreign direct investment need to focus on ensuring higher institutional support with lower levels of corruption while enhancing the skill base of the workforce in an outward-oriented foreign trade system, for example, political risk of destination country (Zhang et al., 2016), educational investment (Murat, 2017), etc.

In general, current studies mainly focus on the impact of OFDI on firms performance, firms' heterogeneity and political risks on OFDI. Relatively few studies have explored the relationship among firm heterogeneity, the political and economic environment, and the performance of OFDI on the firm level.

\section{Model Setting and Data Description}

The performance of foreign investment enterprises will be affected by their own factors, the political risk of foreign investment countries and the economic environment of destination countries. This paper takes the economic environment of the destination country as the control variable and sets the following econometric model:

$$
\ln \text { OUTPUT }_{i t}=\alpha_{0}+\beta X+\gamma Y+\lambda Z+\epsilon_{i t}
$$

Subscript $i$ represents the enterprise investing abroad, and $t$ represents the year. $\varepsilon_{i t}$ is the error term.

OUTPUT $_{i t}$ is firm performance, which is measured by the output of the firm in the current year. $X$ represents the firm's own factors, $Y$ represents the political risk factors of the foreign investment country, and $Z$ represents the economic environment of the destination country.

Here, $\beta X$ is specified as follows:

$$
\begin{aligned}
\beta X_{i t}= & \beta_{1} \mathrm{LNASSET}_{i t}+\beta_{2} \mathrm{EX}_{i t}+\beta_{3} \mathrm{PROV}_{i t}+\beta_{4} \mathrm{EXIST}_{i t} \\
& +\beta_{5} \mathrm{IND}_{i t}+\beta_{6} \mathrm{INVT}_{i t}+\beta_{7} \mathrm{COUNTR}_{i t}
\end{aligned}
$$

$i$ is the OFDI firm and $t$ is the year.

OUTPUT $_{i t}$ is firm performance and is expressed by output in that year.

LNASSET $_{i t}$ is the level of firms' assets, expressed by the total assets of the enterprise in that year;

$\mathrm{EX}_{i t}$ is firm's' export condition, indicating whether the enterprise has exported in that year: 0 refers to the status that the firm did not exported and 1means the firm exported in that year.

$\mathrm{PROV}_{i t}$ refers to the geopolitical factor of the firm, which is represented by the province where the enterprise is registered.

EXIST $_{i t}$ refers to the production and operation experience of the firm, which is represented by the years of existence since the establishment to year 2021 .

$\mathrm{IND}_{i t}$ refers to the industry in which the firm is work with and it is represented by the industry in which the firm makes OFDI.

$\mathrm{INVT}_{\text {it }}$ refers to firms' OFDI experience, using OFDI times in that year; 
COUNTR $_{i t}$ refers to the destination country of OFDI;

$\mathrm{LNGDP}_{i t}$ refers to the market size of destination country, measured by the total GDP at constant dollar prices in year 2010;

$$
\gamma Y=\gamma_{1} \mathrm{GOV}_{i t}+\gamma_{2} \mathrm{POL}_{i t}
$$

$i$ is the OFDI destination country and $t$ is the year of OFDI.

$\mathrm{GOV}_{i t}$ is the government efficiency of the investment of destination country, which is measured by the World Bank Government Effectiveness Index, which is standardized before regression.

$\mathrm{POL}_{i t}$ is the degree of political risk in the investment destination country, which is measured by the World Bank Political Stability and Absence of Violence Terrorism Prediction Index, which is standardized before regression.

$$
\lambda Z=\lambda_{1} \mathrm{LNGDP}_{i t}+\lambda_{2} \mathrm{OPEN}_{i t}+\lambda_{3} \mathrm{LNGDPAV}_{i t}+\lambda_{4} \mathrm{LNLABR}_{i t}
$$

$i$ is the OFDI destination country and $t$ is the year of OFDI.

$\mathrm{OPEN}_{i t}$ is the degree of openness of the destination country, which is measured by the ratio of the total import and export volume of the destination country to that country's GDP of that year.

LNGDPAV $_{\text {it }}$ refers to the level of economic development and the affluence of residents of the destination country, which is measured by the GDP per capita of the destination country in that year, calculated by the total GDP value in constant dollar price of year 2010 divided by the total population of the destination country of that year.

$\mathrm{LNLABR}_{i t}$ refers to the size of the labor market of the destination country and is measured by the number of labor force in the investment destination country.

538 manufacturing enterprises, spanning from 2005 to 2013, with direct investment and import and export trade from China to ASEAN countries are selected $^{1}$. All data are from China Industrial Enterprise Database, Foreign Direct Investment Enterprise Directory of Ministry of Commerce of China and World Bank Database of Governance Indicators.

Capital input, total industrial output value, industrial increased value and enterprise assets are all de-inflationary treatment based on 2004.

According to Cobb-Douglas production function (hereinafter referred to as C-D function), which renders a feasible solution to the evaluation of contribution of material resources and human resources, the growth of output can be presented as:

$$
Y=A K^{\alpha} L^{\beta}
$$

In the formula, $Y$ means gross domestic product; $K$ is capital investment; $L$ is labor investment; $A$ indicates the total factor productivity. $\alpha$ and $\beta$ respectively stands for capital elasticity and labor elasticity.

When $\alpha+\beta=1$, that is, the production scale remains unchanged, we took the natural logarithm of both sides of (5), and derive the linear equation as follows:

${ }^{1}$ Since the authoritative data of China Industrial Enterprise Database in recent seven years have not been released yet, here we just selected data from year 2005 to year 2013. 


$$
\ln Y=\ln A+\alpha \ln K+\beta \ln L+\mu
$$

From the Cobb-Douglas production function, we can understand the contributions of capital input, labor investment and technical level to the service sector.

According to C-D production function, we take the logarithm in Equation (1), and after de-inflation of the original data and logarithmic processing, the data presents the following characteristics. As shown in Table 1, from the mean, standard deviation, maximum values, minimum values, the overall standard deviation of the data, we find that there is no abnormal value.

Table 1. Characteristics of data.

\begin{tabular}{|c|c|c|c|c|c|c|}
\hline Variable & & Mean & Std. Dev. & Min & Max & Observations \\
\hline \multirow[t]{3}{*}{ Inoutput04 } & overall & 12.1467 & 1.8651 & 8.2876 & 17.7628 & $\mathrm{~N}=538$ \\
\hline & between & & 1.8423 & 8.2876 & 17.7628 & $\mathrm{n}=515$ \\
\hline & within & & 0.0999 & 11.5315 & 12.7620 & $\mathrm{~T}$-bar $=1.0447$ \\
\hline \multirow[t]{3}{*}{ lnasset04 } & overall & 11.9333 & 2.1108 & 7.3681 & 18.8306 & $\mathrm{~N}=538$ \\
\hline & between & & 2.0889 & 7.3681 & 18.8306 & $\mathrm{n}=515$ \\
\hline & within & & 0.1183 & 11.0029 & 12.8637 & $\mathrm{~T}$-bar $=1.0447$ \\
\hline \multirow[t]{3}{*}{ ex } & overall & 0.5743 & 0.4949 & 0 & 1 & $\mathrm{~N}=538$ \\
\hline & between & & 1.2254 & 0 & 1 & $\mathrm{n}=515$ \\
\hline & within & & 0.0682 & 0.0743 & 1.0743 & $\mathrm{~T}$-bar $=1.0447$ \\
\hline \multirow[t]{3}{*}{ province } & overall & 34.9591 & 9.7592 & 11 & 63 & $\mathrm{~N}=538$ \\
\hline & between & & 9.8289 & 11 & 63 & $\mathrm{n}=515$ \\
\hline & within & & 0.0000 & 34.9591 & 34.9591 & $\mathrm{~T}$-bar $=1.0447$ \\
\hline \multirow[t]{3}{*}{ existence } & overall & 22.9647 & 11.4544 & 8 & 108 & $\mathrm{~N}=538$ \\
\hline & between & & 11.1474 & 8 & 108 & $\mathrm{n}=515$ \\
\hline & within & & 0.3479 & 18.4647 & 27.4647 & $\mathrm{~T}$-bar $=1.0447$ \\
\hline \multirow[t]{3}{*}{ ind 1} & overall & 28.6245 & 9.0825 & 6 & 45 & $\mathrm{~N}=538$ \\
\hline & between & & 9.0564 & 6 & 45 & $\mathrm{n}=515$ \\
\hline & within & & 0.0682 & 28.1245 & 29.1245 & $\mathrm{~T}-\mathrm{bar}=1.0447$ \\
\hline \multirow[t]{3}{*}{ invtimes } & overall & 1.1784 & 0.5931 & 1 & 6 & $\mathrm{~N}=538$ \\
\hline & between & & 0.5785 & 1 & 6 & $\mathrm{n}=515$ \\
\hline & within & & 0.1258 & -0.3216 & 2.6784 & $\mathrm{~T}-\mathrm{bar}=1.0447$ \\
\hline \multirow[t]{3}{*}{ countryregion } & overall & 6.9944 & 2.8660 & 2 & 10 & $\mathrm{~N}=538$ \\
\hline & between & & 2.8253 & 2 & 10 & $\mathrm{n}=515$ \\
\hline & within & & 0.3931 & 3.4944 & 10.4944 & $\mathrm{~T}$-bar $=1.0447$ \\
\hline \multirow[t]{3}{*}{$\operatorname{lngdp}$} & overall & 25.6142 & 1.4452 & 22.3019 & 27.5226 & $\mathrm{~N}=538$ \\
\hline & between & & 1.4174 & 22.3019 & 27.5226 & $\mathrm{n}=515$ \\
\hline & within & & 0.2138 & 23.3394 & 27.8889 & $\mathrm{~T}-\mathrm{bar}=1.0447$ \\
\hline gov & overall & 0.3546 & 0.2987 & 0 & 1 & $\mathrm{~N}=538$ \\
\hline
\end{tabular}




\begin{tabular}{|c|c|c|c|c|c|c|}
\hline \multicolumn{7}{|c|}{ Continued } \\
\hline & between & & 0.2983 & 0 & 1 & $\mathrm{n}=515$ \\
\hline & within & & 0.0412 & -0.1013 & 0.8104 & $\mathrm{~T}$-bar $=1.0447$ \\
\hline \multirow[t]{3}{*}{ pol } & overall & 0.5590 & 0.2564 & 0 & 1 & $\mathrm{~N}=538$ \\
\hline & between & & 0.2556 & 0 & 1 & $\mathrm{n}=515$ \\
\hline & within & & 0.0480 & 0.1952 & 0.9228 & T-bar $=1.0447$ \\
\hline \multirow[t]{3}{*}{ open } & overall & 1.6463 & 1.0326 & 0.4550 & 4.3730 & $\mathrm{~N}=538$ \\
\hline & between & & 1.0345 & 0.4550 & 4.3730 & $\mathrm{n}=515$ \\
\hline & within & & 0.1536 & 0.1583 & 3.1343 & $\mathrm{~T}$-bar $=1.0447$ \\
\hline \multirow[t]{3}{*}{ lngdpav } & overall & 8.2054 & 1.3756 & 6.4185 & 10.8537 & $\mathrm{~N}=538$ \\
\hline & between & & 1.3745 & 6.4185 & 10.8537 & $\mathrm{n}=515$ \\
\hline & within & & 0.1884 & 6.2694 & 10.1415 & $\mathrm{~T}-\mathrm{bar}=1.0447$ \\
\hline \multirow[t]{3}{*}{ lnlab } & overall & 16.7937 & 1.3294 & 14.6561 & 18.6154 & $\mathrm{~N}=538$ \\
\hline & between & & 1.3158 & 14.6561 & 18.6154 & $\mathrm{n}=515$ \\
\hline & within & & 0.2680 & 15.2932 & 18.2942 & $\mathrm{~T}-\mathrm{b} a \mathrm{r}=1.0447$ \\
\hline
\end{tabular}

\section{Empirical Analysis}

\subsection{Pooled Regression}

As a reference, we first take pool regression, assuming that there is no individual specific effects, which indicating that all firms has the same pooled regression equations.

$$
y_{i t}=\alpha+x^{\prime} \beta+z_{i}^{\prime} \delta+\varepsilon_{i t}
$$

We take the cluster-robust standard error pooled regression, robust standard error regression and standard error regression respectively, results are showed as follows.

As shown in Table 2, the three types of errors have similar results, that all of which are significant in business experience (year of establishment), and none of the others. Since the mixed regression assumes that all firms have the same regression equation, although these firms are all industrial firms, and they all invest in ASEAN countries, they may have similar regression equations. However, because each firm has its own characteristics, there may have time invariable heterogeneities. Therefore, we need to use F-test to further confirm the effectiveness of mixed regression.

The $P$ value of the $\mathrm{F}$ test is 0.0085 , which rejects the null hypothesis. Therefore, there are individual differences and the mixed regression results are not valid. Each firm should be allowed to have its own intercept term.

\subsection{Fixed Effect Regression and Random Effect Model}

We invested two types of specific-effect models respectively, namely Fixed Effects Model (FE) and Random Effect Model (RE).

Fixed effect model regression is shown in Table 3. And the results of random effects model are presented in Table 4. Results from the two models are significantly 
Table 2. Comparison of three pooled regression.

\begin{tabular}{cccccccccccc}
\hline & \multicolumn{3}{c}{ Cluster-Robust standard error } & \multicolumn{2}{c}{ Robust standard error } & \multicolumn{3}{c}{ Standard error } \\
\hline lnoutput04 & Coef. & Std. Err. & $P>|t|$ & Coef. & Std. Err. & $P>|t|$ & Coef. & Std. Err. & $P>|t|$ \\
\hline lnasset04 & 0.7911 & 0.0203 & 0.0000 & 0.7911 & 0.0195 & 0.0000 & 0.7911 & 0.0195 & 0.0000 \\
ex & 0.1080 & 0.0747 & 0.1490 & 0.1080 & 0.0745 & 0.1470 & 0.1080 & 0.0729 & 0.1390 \\
province & 0.0105 & 0.0038 & 0.0060 & 0.0105 & 0.0038 & 0.0060 & 0.0105 & 0.0036 & 0.0030 \\
existence & -0.0008 & 0.0033 & 0.8010 & -0.0008 & 0.0031 & 0.7840 & -0.0008 & 0.0034 & 0.8040 \\
ind1 & -0.0097 & 0.0046 & 0.0370 & -0.0097 & 0.0045 & 0.0340 & -0.0097 & 0.0041 & 0.0180 \\
invtimes & 0.0820 & 0.0716 & 0.2520 & 0.0820 & 0.0696 & 0.2390 & 0.0820 & 0.0609 & 0.1790 \\
countrycode & 0.0284 & 0.0238 & 0.2330 & 0.0284 & 0.0235 & 0.2270 & 0.0284 & 0.0260 & 0.2760 \\
lngdp & -0.0894 & 0.0705 & 0.2050 & -0.0894 & 0.0696 & 0.2000 & -0.0894 & 0.0746 & 0.2320 \\
gov & -0.9220 & 0.4469 & 0.0400 & -0.9220 & 0.4437 & 0.0380 & -0.9220 & 0.4798 & 0.0550 \\
pol & 0.3420 & 0.2209 & 0.1220 & 0.3420 & 0.2209 & 0.1220 & 0.3420 & 0.2398 & 0.1540 \\
openness & -0.2141 & 0.1155 & 0.0640 & -0.2141 & 0.1145 & 0.0620 & -0.2141 & 0.1192 & 0.0730 \\
$\begin{array}{c}\text { lngdpav } \\
\text { lnlab }\end{array}$ & 0.3401 & 0.1205 & 0.0050 & 0.3401 & 0.1182 & 0.0040 & 0.3401 & 0.1178 & 0.0040 \\
_cons & 0.0614 & 0.0268 & 0.0220 & 0.0614 & 0.0267 & 0.0220 & 0.0614 & 0.0262 & 0.0190 \\
\hline
\end{tabular}

Table 3. Fixed effect model.

\begin{tabular}{|c|c|c|c|c|c|c|}
\hline lnoutput04 & Coef. & Std. Err. & $t$ & $P>|t|$ & [95\% Conf. & Interval] \\
\hline lnasset04 & 0.5269 & 0.2556 & 2.0600 & 0.0640 & -0.0357 & 1.0900 \\
\hline ex & 0.0404 & 0.3733 & 0.1100 & 0.9160 & -0.7812 & 0.8620 \\
\hline province & 0 (omitted) & & & & & \\
\hline existence & 0.0105 & 0.0620 & 0.1700 & 0.8690 & -0.1261 & 0.1470 \\
\hline ind 1 & -0.1297 & 0.4335 & -0.3000 & 0.7710 & -1.0861 & 0.8267 \\
\hline invt & 0.1418 & 0.2240 & 0.6300 & 0.0540 & -0.3513 & 0.6349 \\
\hline countrycode & 0.1545 & 0.1649 & 0.9400 & 0.3690 & -0.2084 & 0.5174 \\
\hline lngdp & -0.3018 & 0.3035 & -0.9900 & 0.0342 & -0.9698 & 0.3663 \\
\hline gov & -2.1007 & 3.1816 & -0.6600 & 0.1340 & -9.1033 & 4.9020 \\
\hline pol & 0.1247 & 0.7495 & 0.1700 & 0.5230 & -1.5250 & 1.7744 \\
\hline openness & -0.0910 & 0.4121 & -0.2200 & 0.8710 & -0.9981 & 0.8161 \\
\hline lngdpav & 0.5488 & 0.6908 & 0.7900 & 0.4440 & -0.9716 & 2.0691 \\
\hline lnlab & -0.0021 & 0.6908 & -0.0300 & 0.9800 & -0.1862 & 0.1819 \\
\hline _cons & 12.1475 & 16.0276 & 0.7600 & 0.4640 & -23.1290 & 47.4240 \\
\hline sigma_u & \multicolumn{6}{|c|}{1.5178} \\
\hline sigma_e & \multicolumn{6}{|c|}{0.4161} \\
\hline rho & \multicolumn{6}{|c|}{0.9301 (fraction of variance due to $u \_i$ ) } \\
\hline
\end{tabular}


Table 4. LSDV model.

\begin{tabular}{|c|c|c|c|c|c|c|}
\hline lnoutput04 & Coef. & Robust Std. Err. & $t$ & $P>|t|$ & [95\% Conf. & Interval] \\
\hline \multicolumn{7}{|l|}{ province } \\
\hline 12 & 1.0212 & 0.2850 & 3.5800 & 0.0000 & 0.4613 & 1.5811 \\
\hline 13 & 0.8374 & 0.2947 & 2.8400 & 0.0050 & 0.2585 & 1.4163 \\
\hline 14 & 0.4914 & 0.3767 & 1.3000 & 0.1930 & -0.2487 & 1.2314 \\
\hline 15 & 0.9430 & 0.2769 & 3.4100 & 0.0010 & 0.3989 & 1.4870 \\
\hline 21 & 1.0144 & 0.3769 & 2.6900 & 0.0070 & 0.2740 & 1.7549 \\
\hline 22 & 0.5676 & 0.2779 & 2.0400 & 0.0420 & 0.0216 & 1.1136 \\
\hline 23 & 0.9678 & 0.6095 & 1.5900 & 0.1130 & -0.2297 & 2.1654 \\
\hline 31 & 0.7770 & 0.2042 & 3.8100 & 0.0000 & 0.3758 & 1.1782 \\
\hline 32 & 0.8884 & 0.1801 & 4.9300 & 0.0000 & 0.5346 & 1.2422 \\
\hline 33 & 0.5878 & 0.1712 & 3.4300 & 0.0010 & 0.2513 & 0.9242 \\
\hline 34 & 0.9231 & 0.4227 & 2.1800 & 0.0290 & 0.0927 & 1.7536 \\
\hline 35 & 0.9861 & 0.2830 & 3.4800 & 0.0010 & 0.4300 & 1.5421 \\
\hline 36 & 1.3840 & 0.3421 & 4.0500 & 0.0000 & 0.7118 & 2.0562 \\
\hline 37 & 1.2366 & 0.1827 & 6.7700 & 0.0000 & 0.8777 & 1.5955 \\
\hline 41 & 0.7422 & 0.3686 & 2.0100 & 0.0450 & 0.0180 & 1.4664 \\
\hline 42 & 0.8130 & 0.2836 & 2.8700 & 0.0040 & 0.2557 & 1.3702 \\
\hline 43 & 1.4494 & 0.1882 & 7.7000 & 0.0000 & 1.0797 & 1.8192 \\
\hline 44 & 1.0170 & 0.1973 & 5.1600 & 0.0000 & 0.6294 & 1.4045 \\
\hline 45 & 1.2179 & 0.2507 & 4.8600 & 0.0000 & 0.7254 & 1.7104 \\
\hline 46 & 1.1407 & 0.1692 & 6.7400 & 0.0000 & 0.8083 & 1.4731 \\
\hline 50 & 1.1954 & 0.1808 & 6.6100 & 0.0000 & 0.8403 & 1.5506 \\
\hline 51 & 0.4819 & 0.3251 & 1.4800 & 0.1390 & -0.1568 & 1.1205 \\
\hline 52 & 0.8091 & 0.2362 & 3.4300 & 0.0010 & 0.3450 & 1.2732 \\
\hline 53 & 0.8814 & 0.2423 & 3.6400 & 0.0000 & 0.4054 & 1.3574 \\
\hline 61 & 0.1017 & 0.2780 & 0.3700 & 0.7150 & -0.4446 & 0.6479 \\
\hline 62 & 1.0495 & 0.3150 & 3.3300 & 0.0010 & 0.4305 & 1.6684 \\
\hline _cons & 0.7086 & 1.4709 & 0.4800 & 0.6300 & -2.1814 & 3.5986 \\
\hline
\end{tabular}

different. In fixed effect model, only total assets, investment times and market scale is statistically significant. While in random effect model, besides total assets and market scale, location, investment industry, host country's government effectiveness, host country's openness, host country's residential wealth level and host country's labor level are all statistically significant.

In addition, to further test whether the province where the firm is located has a geographic impact on the output of OFDI companies, the LSDV test is carried out here. Most of the $P$ values of dummy variables representing the province where firms are located are at $1 \%$ or $5 \%$, with only two exceptions. Therefore, 
firms' location does have an impact on their output performance. (See Table 4)

Since the results of two models are significantly differentiated (as shown in Table 3 and Table 5), how the roles as investment experience, which is statistically significant in fixed effect model, firm location, industry of firm's investment, as well as government effectiveness, openness and labor level of destination countries played in firms' performance, needs to be further identified.

To further confirm the determinants of OFDI firms' output, we take the Hausman test to determine the effectiveness and validity of the fixed effect model and random effect model results.

Test results in Table 6 show that $P$ value equals 0.49 , which strongly accept the $\mathrm{H}_{0}$ hypothesis, indicating that the difference in coefficients is not systematic, and random effect regression is effective.

\subsection{Results}

Analyzing from the regression results (Table 5), the conditions of the enterprise, for example, the total assets, the province, enterprise investment industry has a significant influence on the performance of exterior investment of enterprises. Whether enterprise exports, experience of enterprise management, enterprise investment experience, and destination country for external investment performance do not present a statistically significant. The political risk of the destination country has no significant influence on the performance of enterprises' foreign

Table 5. Random effect model.

\begin{tabular}{|c|c|c|c|c|c|c|}
\hline Inoutput & Coef. & Std. Err. & $t$ & $P>|t|$ & [95\% Conf. & Interval] \\
\hline lnasset & 0.7870 & 0.0197 & 39.9800 & 0.0000 & 0.7484 & 0.8255 \\
\hline ex & 0.1103 & 0.0725 & 1.5200 & 0.1280 & -0.0317 & 0.2523 \\
\hline prov & 0.0096 & 0.0038 & 2.5100 & 0.0120 & 0.0021 & 0.0170 \\
\hline exist & -0.0016 & 0.0032 & -0.5100 & 0.6120 & -0.0079 & 0.0046 \\
\hline ind & -0.0096 & 0.0046 & -2.0700 & 0.0390 & -0.0187 & -0.0005 \\
\hline invt & 0.0689 & 0.0636 & 1.0800 & 0.2780 & -0.0557 & 0.1936 \\
\hline countr & 0.0324 & 0.0218 & 1.4800 & 0.1380 & -0.0104 & 0.0752 \\
\hline $\operatorname{lngdp}$ & -0.1108 & 0.0634 & -1.7500 & 0.0800 & -0.2350 & 0.0134 \\
\hline gov & -0.8805 & 0.4231 & -2.0800 & 0.0370 & -1.7097 & -0.0513 \\
\hline pol & 0.2916 & 0.2039 & 1.4300 & 0.1530 & -0.1080 & 0.6911 \\
\hline open & -0.2162 & 0.1042 & -2.0800 & 0.0380 & -0.4204 & -0.0121 \\
\hline lngdpav & 0.3474 & 0.1134 & 3.0600 & 0.0020 & 0.1251 & 0.5696 \\
\hline lnlabr & 0.0514 & 0.0248 & 2.0800 & 0.0380 & 0.0029 & 0.1000 \\
\hline _cons & 1.9882 & 1.2918 & 1.5400 & 0.1240 & -0.5436 & 4.5200 \\
\hline sigma_u & \multicolumn{6}{|c|}{0.6825} \\
\hline sigma_e & \multicolumn{6}{|c|}{0.4161} \\
\hline rho & \multicolumn{6}{|c|}{0.7291 (fraction of variance due to $\mathrm{u} \_\mathrm{i}$ ) } \\
\hline
\end{tabular}


Table 6. Hausman test (Fixed Effects and Random Effects).

\begin{tabular}{ccccc}
\hline & & \multicolumn{3}{c}{---coefficients --- } \\
\hline & $(b)$ & $(B)$ & $(b-B)$ & $\operatorname{sqrt}\left(\operatorname{diag}\left(V_{b}-V_{B}\right)\right)$ \\
\hline Inasset & 0.5269 & 0.7870 & -0.2601 & S.E. \\
ex & 0.0404 & 0.1103 & -0.0699 & 0.2531 \\
exist & 0.0105 & -0.0016 & 0.0121 & 0.3639 \\
ind & -0.1297 & -0.0096 & -0.1201 & 0.0615 \\
invt & 0.1418 & 0.0689 & 0.0729 & 0.4316 \\
countr & 0.1545 & 0.0324 & 0.1221 & 0.2147 \\
lngdp & -0.3018 & -0.1108 & -0.1909 & 0.1618 \\
gov & -2.1007 & -0.8805 & -1.2202 & 0.2928 \\
pol & 0.1247 & 0.2916 & -0.1668 & 3.1249 \\
open & -0.0910 & -0.2162 & 0.1252 & 0.7096 \\
lngdpav & 0.5488 & 0.3474 & 0.2014 & 0.3931 \\
lnlabr & -0.0021 & 0.0514 & -0.0536 & 0.6763 \\
cons & 12.1475 & 1.9882 & 10.1593 & 0.0792 \\
\hline
\end{tabular}

$b=$ consistent under Ho and Ha; obtained from xtreg; $B=$ inconsistent under Ha, efficient under Ho; obtained from xtreg; Test: Ho: difference in coefficients not systematic; chi2 $(13)=(b-B)^{\prime}\left[\left(V_{b}-\mathrm{V}_{\mathrm{B}}\right)^{(-1)}\right](b-B)$ $=0.49$.

investment, while the government efficiency of the destination country, as well as the market size, openness, affluence and labor force level that characterize the economic development of the destination country, have significant influence on the performance of enterprises' foreign investment. In this study, the target countries are selected as ASEAN countries, which are all developing countries and have certain similarities. Therefore, in this sample study, the target countries do not show statistical significance.

From the perspective of enterprises' own factors, the regression results show that the total assets of firms have a significant positive effect on the performance of firms' foreign investment: the coefficient is 0.787 , indicating that an increase of $1 \%$ of firms' total assets can increase the performance of firms' foreign investment by $0.787 \%$. Where the firm is located, namely the geographical location of the firm and the investment industry of the firm, has a weak negative impact on the performance of the firm's foreign investment. In terms of the firm's own factors, the total assets of the firm are the core factor affecting the investment of the firm.

From the perspective of the political risk of the target country, the regression results show that the governance capacity of ASEAN countries has a significant impact on the performance of firms' foreign investment while the political stability of ASEAN countries has no significant impact on the performance of Chinese firms' foreign investment. It is worth noting that there is a significant nega- 
tive correlation between the governance efficiency of ASEAN countries and the performance of Chinese outbound investment firms. This conclusion is contrary to the normal economic theory, indicating that China's outbound investment in ASEAN countries does have the characteristics of risk preference.

In terms of the economic environment of the destination country, the regression results show that Chinese firms are more sensitive to the economic environment of ASEAN. The degree of openness, market size and affluence of the destination country, as well as the level of labor force all have a significant impact on corporate performance. Among them, market size and openness have a negative impact on corporate performance while affluence and labor force have a positive impact, which again confirm that firms have a risk preference for investment in ASEAN countries.

\section{Conclusion and Recommendation}

Based on the data of 538 industrial firms invested by China in ASEAN countries, this paper explores the effects of firm heterogeneity, political risk and economic environment in the investing countries on firm performance. From the firm level, it provides reference for the research on the going-out and its performance of developing countries' firms. However, as the samples are taken from the database of industrial firms, it does not include the research on the overseas investment of service firms, which is a limitation of this study. Therefore, findings of the research will provide reference for OFDI decisions of manufacturing firms in developing countries.

The results show that the heterogeneity of the firm, the political and economic environment of the investment country have different effects on the firm performance in the time and sample range of this study. This research sample shows that Chinese industrial firms have risk preference in the process of overseas investment.

It is worth noting that political risk in the destination country does not have a negative impact on firm performance, and political risk is not statistically significant in this study.

At the same time, government governance level is negatively correlated with firm performance. These results indicate that Chinese manufacturing firms do not obviously avoid the investment in ASEAN countries due to the lack of political risk and government governance level of destination countries, and they have the characteristics of risk preference. Therefore, firms should take full account of the political, economic and social factors of the destination country, and do a good job of risk assessment and risk prevention from the aspects of firms themselves and the investment industry.

The total assets of firms have a significant positive effect on the improvement of firm performance, which indicates that China's manufacturing firms are still in the stage of "Mass Manufacturing", and the improvement of firm output is still mainly dependent on capital. China is in the transformation period of in- 
dustrial structure upgrading and faces two tasks of developing strategic emerging industries and transforming traditional industries. The upgrading of manufacturing industry is the core content of the current development of real economy. Therefore, we should pay attention to the technological innovation of manufacturing firms, especially the technological innovation of manufacturing industry. In promoting manufacturing firms to go global and the development of high-end manufacturing, attention should be paid to the following aspects: First, we need to strengthen the standardization of the political, economic and social risk assessment system of the destination countries, and establish a systematic and sound investment risk prevention mechanism; second, we need to develop high-end manufacturing, gradually change the capital-driven output growth model, increase firm R\&D capital investment, promote technological innovation, further improve the technological level of firms, improve the total factor productivity of firms, and promote firm output growth through productivity growth; third, we need to promote the industrialization of innovative technologies, increase the rate of return on investment in manufacturing R\&D, and closely combine technological innovation with actual production; fourth, we should focus on the cultivation of high-end manufacturing talents. Through co-development programs with universities and research centers, introduction programs from overseas countries, or cooperation in scientific research and technology development, to develop high-end and internationalized manufacturing talents.

\section{Supporting Projects}

OFDI's performance from the perspective of firm heterogeneity, Beijing URT Project (2020J00064).

\section{Conflicts of Interest}

The authors declare no conflicts of interest regarding the publication of this paper.

\section{References}

Baltabaev, B. (2012). FDI and Total Factor Productivity Growth: New Macro Evidence. Econometric Society Australasian Meeting 2012.

Cong, H. (2020). Research on the Theory of Heterogeneous Enterprises Based on Exports and Foreign Direct Investment. Foreign Economic Relations \& Trade, 4, 18-20.

Helpman, E., Melitz, M. J., \& Yeaple, S. R. (2004). Export Versus FDI with Heterogeneous Firms. American Economic Review, 94, 300-316. https://doi.org/10.1257/000282804322970814

Li, H. Y. (2021). A Study of OFDI Technology-Seeking Motivation and Productivity Improvement and Their Heterogeneities. Studies in Science of Science, 39, 254-263.

Lin, Z. X., Liu, J. J., Wang, M. X., Liu, S. L., \& Xie, X. L. (2020). The Impact of Exchange rate Fluctuation on OFDI in China-From the Perspective of Enterprise Heterogeneity. Northern Economy and Trade, 11, 99-102.

Mamta, C. (2014). Which Factor Dominates FDI: Institutional or Economic? Proceedings 
of 10th Global Business and Social Science Research Conference, Beijing, 23-24 June 2014.

Morck, R., Yeung, B., \& Zhao, M. (2008). Perspectives on China's outward Foreign Direct Investment. Journal of International Business Studies, 239, 337-350. https://doi.org/10.1057/palgrave.jibs.8400366

Murat, M. (2017). International Students and Investments Abroad. Global Economy Journal, 17, 1-33. https://doi.org/10.1515/gej-2016-0037

Tao, C. Q., \& Xu D. M. (2020). Impact of Leverage Deviation of Non-Financial Corporates on Enterprise Efficiency. Contemporary Finance \& Economics, 10, 111-123.

Wen, C. Y. (2020). Analysis of the Impact of Enterprise Heterogeneous Market Power on Total Factor Productivity Based on China's Manufacturing Enterprise Data Abstract. Shanghai Economy, 1, 41-56.

$\mathrm{Xu}$, J. W. (2021). On the Prevention Path of Political Risks in the Foreign Investment of "The Belt and Road Initiative"-Taking Promoting the Internationalization of RMB as a Breakthrough Point. Shanghai Law Society. Collection of Shanghai Legal Research (Volume 1, Volume 49, 2021)_Proceedings of the Research Group on National Security Rule of Law of Shanghai Law Society, 2021: 11.

Yan, J. (2019). Research on Executive Background Heterogeneity and Enterprise Performance. Academic Journal of Humanities \& Social Sciences, 2, No. 6.

Yang, L. X., Shen, C. H., \& Yin, D. S. (2019). How OFDIs Affect the Output of HomeCountry Firms. The Journal of World Economy, 42, 77-100.

Zhang, Y., Fang, M., Jiang, T., \& Nie, H. (2016). Contractual Hazard, Political Hazard and FDI Ownership Structure in Joint-Venture Enterprises in China. Review of Development Economics, 20, 14-24. https://doi.org/10.1111/rode.12211 